\title{
Mutation based Atom Search Optimization Algorithm for Hyperparameter Optimization of the DenseNet121 Architecture for Cervical Cancer Classification
}

B Chitra ( $\nabla$ bchitra.research@gmail.com )

Noorul Islam College of Engineering: Noorul Islam Centre For Higher Education

S.S. Kumar

Noorul Islam College of Engineering: Noorul Islam Centre For Higher Education

Keywords:

Posted Date: March 17th, 2021

DOI: https://doi.org/10.21203/rs.3.rs-302143/v1

License: (c) (i) This work is licensed under a Creative Commons Attribution 4.0 International License.

Read Full License 


\section{Abstract}

The authors have requested that this preprint be removed from Research Square. 